\title{
Shariah Compliance Risk Management in the Provision of Wakaf-Zakat Housings
}

\author{
PUTERI NUR FARAH NAADIA M.F. \& KHAIRUDDIN A.R. ${ }^{1}$
}

\begin{abstract}
The presence of risks in development of wakaf-zakat housings, as in other developments, are inevitable. The risks if it is not managed properly may cause loss and damages to properties. Consequently, a proper management of risks is crucial in order to mitigate risks. However, the management of risk in the provision of wakaf-zakat housings, as stated in manual guidelines published by JAWHAR (2009; 2007) seems inadequate as it focuses only on the protection of wakaf and zakat properties. Due to the inadequacy, in particular to benefit the asnafi and needy, loss and damages occur upon occurrence of risks probably are due to syubhah methodology adopted in managing risks. Consequently, a study is conducted to review literature on the practice of conventional and Shariah compliance risk management leading to a synthesis framework that could then be recommended for adoption for Shariah compliance risk management in the provision of wakaf-zakat housings. The study is an extended research on the protection of wakaf-zakat properties for the needy and poor via takaful. The study combines review of literature and intensive discussions with experts specializing in the Shariah, wakaf and zakat, and practitioners i.e. developers and consultants involved in wakaf-zakat housings and their contents projects. Findings of the study suggest that: Shariah compliance risk management in the provision of wakaf-zakat housings are not being practiced; the practice lack comprehensiveness in terms of the management of risks in the provision of wakaf-zakat housings, and; the outcome of the study is a synthesis list comprising of processes and steps in Shariah compliance risk management in the provision of wakaf-zakat housings is produced.
\end{abstract}

Keywords: risks, risk management, housings, Shariah, development

Activities in construction and maintenance of wakaf-zakat housings are exposed to a variety of risk. Such risks, for instance, financial i.e. funding of projects, client and contractor cash flows, payments, construction product i.e. time management, completion, delay, insufficient materials, disputes, accidents and natural disasters if are not managed properly may cause loss and damages. Potential losses and damages can be mitigated and controlled through management of risks.

Risk management is a process of handling risk that includes identification, assessment and techniques to respond to risks (Nurul Shahnaz \& Boey 2015). Puteri Nur Farah Naadia \& Khairuddin (2017) has identified the provision of risk protection through insurance and takaful. However, no specific provision provided on the Shariah compliant risk management in the provisions wakaf-zakat housings provided in the manual guidelines of wakaf and zakat and official reports by respective Malaysian States Religious Departments (MAINs). It seems that the practice of risk management in the provision of wakaf-zakat housings therefore appears to be inadequate. Due to the inadequacy, in particular to benefit the asnaf and needy, loss and damages occur upon occurrence of risks probably are due to syubhah methodology adopted in managing risks.

\footnotetext{
${ }^{1}$ Puteri Nur Farah Naadia M.F*, ), Ph. D., (Corresponding author), Assistant Prof. at Department of Quantity Surveying, Kulliyyah of Architecture and Environmental Design, International Islamic University Malaysia, GOMBAK, Malaysia. Email: puteri@iium.edu.my; Khairuddin Abdul Rashid, $\mathrm{Ph}$. D. Professor at Faculty of Architecture, Planning \& Surveying, Universiti Teknologi MARA 40450 SHAH ALAM, Selangor, Malaysia. Email: dqs1431959@gmail.com

https://doi.org/10.24035/ijit.19.2021.200
} 
Consequently, a study reported herein, to review literature on the practice of conventional and shariah compliance risk management leading to a synthesis framework that could then be recommended for adoption for shariah compliance risk management in the provision of wakafzakat housings. The study combines literature review and intensive interview with Malaysian States Religious Departments (MAINs) officers, practitioners and experts specializing in shariah, Islamic finance, takaful, and construction.

\section{Risk and the Concept of Risk Management}

Generally, there is no single definition of 'risk'. According to Syed Othman Alhabshi et. al. (2012) risk can be defined as uncertainty concerning the occurrence of loss or uncertainty regarding loss. In addition, risk is also used to describe events where there is uncertainty in the outcome, which will prevent an entity or a party from achieving the desirable objective. The presence of risks drives groups and individuals to seek solutions by the way of managing risks. Risk management refers to a systematic approach of handling potential losses that includes the process of identifying, assessing and prioritizing risk (Nurul Shahnaz \& Boey 2015).

Conventionally, objectives of risk management can be classified into two that are pre-loss and post-loss objectives. Pre-loss objectives of risk management refers to management of potential losses before the occurrence of risks such as preparation of potential losses in the most economical way, reduction of anxiety, and meeting requirement of legal obligation (Redja \& McNamara 2017). Meanwhile, post-loss objectives of risk management refers management of potential losses upon the occurrence of risks, for instance maximum recovery of losses in terms of operation of a business or project, stability of earnings, continuation of growth and social responsibility to minimize the effects of losses on others (Redja \& McNamara 2017).

According to Redja \& McNamara (2017) achievement of the objectives of conventional risk management is essential in ensuring a proper management of risks. Redja \& McNamara (2017) and Nurul Shahnaz \& Boey (2015) identified that there are four specific steps in the process of conventional risk management as presented in Table 1:

Table 1: Conventional Risk Management Processes and Steps

\begin{tabular}{|c|c|c|}
\hline Process & Step & Descriptions \\
\hline Identify & $\begin{array}{l}\text { 1. Identification of loss } \\
\text { exposures. } \\
\text { - Establishment of context. } \\
\text { - Classification of risks into } \\
\text { specified categories. } \\
\end{array}$ & $\begin{array}{l}\text { - Potential losses and damages to physical and } \\
\text { intangible assets, income, human resources and } \\
\text { liability are identified. } \\
\text { - Classification of types of risks, their sources, } \\
\text { consequence and impacts for assessment. }\end{array}$ \\
\hline Assess & $\begin{array}{l}\text { 2. Measurement and } \\
\text { analyzation of loss exposures. } \\
\text { - Evaluation. } \\
\text { - Analysis. }\end{array}$ & $\begin{array}{l}\text { - Severity and occurrence of risks are evaluated. } \\
\text { - Categorization by the order of importance/hierarchy } \\
\text { based on the severity and occurrences. } \\
\text { - Measurement based on several techniques such as } \\
\text { risk rating scales or risk management techniques. } \\
\text { - Greater severity and occurrence are considered } \\
\text { crucial and required prioritization. }\end{array}$ \\
\hline \multirow[t]{2}{*}{ Prioritize } & $\begin{array}{l}\text { 3. Selection of appropriate } \\
\text { techniques for treating risks } \\
\text { - Techniques as response.. }\end{array}$ & $\begin{array}{l}\text { - } 2 \text { categories of appropriate techniques; risk control } \\
\text { \& risk financing. }\end{array}$ \\
\hline & a. Risk control. & $\begin{array}{l}\text { - Methods that limit the frequency or severity of } \\
\text { losses. } \\
\text { - Risk avoidance - Evade the exposure to loss. } \\
\text { - Risk prevention - Efforts that effect the frequency of } \\
\text { losses. } \\
\text { - Risk reduction - Techniques to reduce the potential } \\
\text { severity of losses that do occur. }\end{array}$ \\
\hline
\end{tabular}




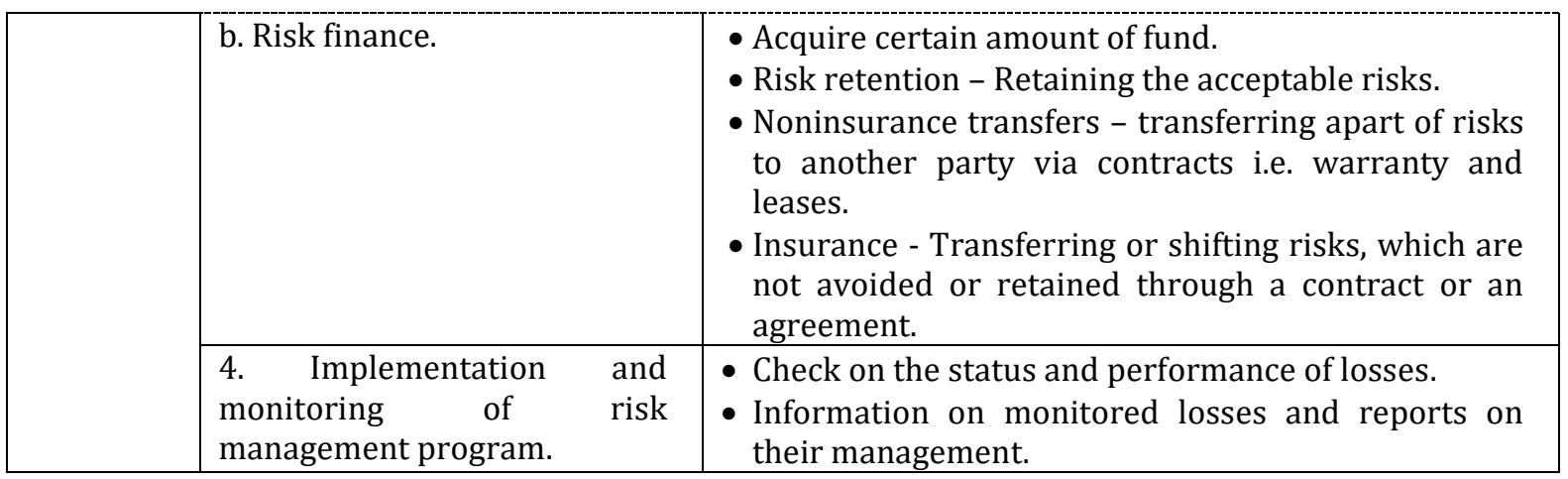

\section{Provision of Wakaf-Zakat Housings and Their Contents}

In Islam, wakaf and zakat are among the key instruments that are available to provide assistance for the ummah. Wakaf refers to an act of dedication (transferring of personal ownership to permanent ownership of Allah) of usufruct of specific properties for pious purposes (Siti Mashitoh 2006). Zakat refers to obligatory worship ordained by Allah to Muslims in assisting the poor and needy. Zakat collected are to be expended to asnaf. Specifically, in the context of properties, past reports and literature have shown the involvement of wakaf and zakat in the provision of housing the ummah that include development of wakaf properties and distribution of zakat fund for the purposes of repairing building and repairing existing houses for the asnaf (refers to recipients in the categories of either asnaf faqr or poor)

The provision of wakaf-zakat housings exists since the time of the Prophet Muhamad and the Companions but have been expanded especially during the reign of the Ottoman Empire (Ram Al Jaffri et. al. 2016; Siti Mashitoh 2006). The provision of housing in zakat has been expanded especially during the reign of the Umayyah. Caliph Umar Abdul Aziz has introduced several reforms including management of zakat surplus. The excess of zakat funds was used for investment including building houses for recipients in need (Ram Al Jaffri et. al. 2016).

Development of houses, including for wakaf-zakat is categorized into two stages that are construction stage and completed unit stage. In construction stage, works are divided according to two main phases that are: pre-contract and post-contract. Each phase involves specific process of construction procurement (Khairuddin1998). Upon completion of construction works, maintenance of completed units are divided into two phases i.e. with defect liability period and without defect liability period.

\section{Shariah Compliance Risks and Risks Management}

In the context of mua'malah, risk is defined based on the word 'khatar' which means fear of loss or destruction (Asyraf Wajdi 2012). The concept of risk in Islam relates with the faith of qada' and qadar-to submit and leave matters to the will of Allah, but only upon taking utmost precaution and striving to achieve the best in this world and the hereafter. Some shariah scholars in the opinions that risk is associated with trials and tribulation tests by Allah in order to gauge and uplift man's faith (al-Quran 2: 155) through perseverance, patience and endurance (Mohd Fadzli et. al. 2015).

However, it is emphasized that in Islam the concept of patient and endurance are not just suffering in silence, but to plan and take actions in order to address risks. In Islam, Muslims are encouraged to improve their life and achieve best in this world and the hereafter. Therefore, Muslims are required to anticipate potential losses and take utmost precautions to mitigate them. In addition, the concept of anticipation and mitigation of risks are also based on the advices of Prophet Ya'akob (Jacob) to his children when they entered Egypt (al-Quran 12:43; 12:47) and hadith of Prophet Muhammad regarding leaving fate to the will and decree of Allah. (A Bedouin asked Prophet Muhammad whether he should tie his camel and leave it to Allah or completely leave it to the will of Allah. The Prophet Muhammad instructed him to leave the fate of his camel to Allah only after he ties it). 
Shariah compliance risk management can be defined as systematic manners and process of identifying, measuring, controlling and monitoring, and reporting of risks to mitigate any possibilities of losses and damages where the operations and methods within the ambit of shariah principles and practice (Mohd Fadzli et. al. 2015; Mohd Nazri 2013). According to Mohd Fadzli et. al (2015) the practice of shariah risk management is based on one of the objectives of the shariah i.e. preservation of wealth and legal maxims. Preservation of wealth refers to protection property and encouragement to seek the bounties of Allah in line with the principles of mua'malat (Mohd Fadzli et. al. 2015).

In addition, the Shariah principles in the legal maxims that are apply to risk management include (1) the benefit of a thing in a return for the liability for loss from that thing (Article 85), The concept of entitlement to return or profit is for those who also bear the liability for something (Mohd Fadzli Yusof, 2015); (2) harm is to be removed (Article 20); (3) the repelling of mischief is preferred to the acquisition of benefits (Article 20) and; (4) harm is to be resisted to the extent possible (Article 31) (Tyser, et. al, 2001). Mohd Fadzli et. al (2015) and Mohd Nazri Chik (2013) identified there are 5 specific steps in the process of Shariah compliance risk management as presented in Table 2:

Table 2: Shariah Compliance Risk Management Processes and Steps

\begin{tabular}{|c|c|c|}
\hline Process & Steps & Descriptions \\
\hline Identify & $\begin{array}{l}\text { 1. Identifying and documenting } \\
\text { Shariah compliance risks }\end{array}$ & $\begin{array}{l}\text { - Develop Shariah compliance risks profile - } \\
\text { description, classification of types of risks and } \\
\text { causal factors of risks }\end{array}$ \\
\hline Measure & $\begin{array}{l}\text { 2. Assessment and measurement of } \\
\text { Shariah compliance risks } \\
\text { a. Assessment on the permissibility } \\
\text { of identified risks } \\
\text { b. Acceptance of risk } \\
\text { c. Evaluation of accepted risks }\end{array}$ & $\begin{array}{l}\text { - Inherent risks must adhere to the requirement } \\
\text { and permissibility of the Shariah } \\
\text { - Identified risks need to be evaluated on the } \\
\text { basis of the type of houses and the contents } \\
\text { therein, and methods of financing used for the } \\
\text { houses to be undertaken. } \\
\text { - Risks are permissible and accepted if the } \\
\text { elements such as types of assets, source of } \\
\text { contributions, and lawful cause of loss involve } \\
\text { are fully or at least } 2 / 3 \text { compliant with the } \\
\text { Shariah }\end{array}$ \\
\hline Control & $\begin{array}{l}\text { 3. Selection of appropriate techniques } \\
\text { to mitigate Shariah compliance risks } \\
\text { a. Risk prevention } \\
\text { b. Risk reduction } \\
\text { c. Risk retention } \\
\text { d. Takaful (Islamic Insurance) } \\
\text { e. Hedging }\end{array}$ & $\begin{array}{l}\text { - Refers to actions to mitigate Shariah } \\
\text { compliance risks } \\
\text { - Total avoidance of risks is condemned in the } \\
\text { Shariah } \\
\text { - Efforts that effect the frequency of losses } \\
\text { - Techniques to reduce the potential severity of } \\
\text { losses } \\
\text { - Retaining the acceptable risks } \\
\text { - A mechanism in which risks are shared among } \\
\text { participants of a takaful fund that are willing } \\
\text { to share the consequences of the risks. } \\
\text { - Defined risks are transferred to another party } \\
\text { via standard agreements i.e. leases and } \\
\text { indemnity agreements }\end{array}$ \\
\hline Monitor & $\begin{array}{l}\text { 4. Implementation and monitoring of } \\
\text { risk management program }\end{array}$ & - Document actions taken/required to mitigate \\
\hline Report & $\begin{array}{l}\text { 5. Reporting on risk management } \\
\text { program }\end{array}$ & $\begin{array}{l}\text { - Information on monitored risks } \\
\text { - Reports on their management }\end{array}$ \\
\hline
\end{tabular}

In identifying shariah permissibility of risks for the purpose of risk management in housings, those risks need to be evaluated on the basis of the type of houses and the contents therein, and 
methods of financing used for the houses to be undertaken (Ashraf \& Muhammad Ali Jinnah 2014). Risks are permissible and accepted if the elements such as types of assets, source of contributions, and lawful cause of loss involve are fully or at least $2 / 3$ compliant with the Shariah (Ashraf \& Muhammad Ali Jinnah 2014). In addition, total avoidance of risk is condemned in managing risks. Risk avoidance is a negative approach of risk management technique as it repudiates the presence of risks in a specific mua'malat or project (Mohd Fadzi et. al. 2015). In terms of protection of risk, the concept of risk transfer in insurance is haram. Shariah only allows and permits protection of risk based on the concept of risk-sharing that is applied through a protection scheme i.e. takaful.

In the provision of wakaf-zakat housings, there is inadequacy of shariah compliant risk management in terms of its processes, details techniques, and operations as stated in the manual guidelines issued by JAWHAR (Department of Wakaf, Zakat and Hajj). In terms of management of wakaf properties, based on the 'Manual Pengurusan Tanah Wakaf' (Jawhar 2009) there is a provision of wakaf properties' protection i.e. the process of acquiring and claim of insurance. In addition, in the context of zakat management, the assistance of zakat fund for protection of asnaf's (al-Quran 9: 60) houses and their contents via takaful contributions is available in the 'Manual Pengurusan Agihan Zakat' (Jawhar 2007). For works under construction, the authorities i.e. respective MAINs leave the practice of risk management to other party i.e. by virtue to the developers or property consultants that handling wakaf-zakat housings projects (Respondent 1 : MAINs, 29 August 2019). Upon completion of construction works, the management of risks for completed houses including contents therein are depends on the beneficiaries or recipients (Respondent 2: MAINs, 24 June 2018).

\section{Methodology}

The study combines review of literature and intensive discussions with experts specializing in the shariah, wakaf and zakat, and practitioners i.e. developers and consultants involved in wakafzakat housings and their contents projects. From the review of the literature, a synthesis list comprising of processes and steps in shariah compliance risk management is produced. The list is presented in a series of interview sessions for experts to evaluate on the applicability of the processes and steps in managing risks in the provision of wakaf-zakat housings.

\section{Results and Discussions}

Data collected from literature and interviews conducted were analysed, synthesized and presented in Table 3.

Table 3: A Synthesis List Comprising of Processes and Steps in Shariah Compliance Risk Management in the Provision of Wakaf-Zakat Housings

\begin{tabular}{|c|c|c|c|c|}
\hline Process & Steps & Conventional & Shariah & $\begin{array}{l}\text { Agreement of } \\
\text { Respondents } \\
\end{array}$ \\
\hline \multirow[t]{4}{*}{ Identify } & 1. Identification of loss exposures & 1 & l & $\checkmark$ \\
\hline & a. Establishment of context & / & / & $\checkmark$ \\
\hline & b. Classification of risks & / & / & $\checkmark$ \\
\hline & $\begin{array}{l}\text { c. Documentation of Shariah compliance } \\
\text { risks }\end{array}$ & $\mathrm{X}$ & / & $\checkmark \quad 3$ \\
\hline \multirow{3}{*}{$\begin{array}{l}\text { Assess } \\
\& \\
\text { Measure }\end{array}$} & $\begin{array}{l}\text { 2. Measurement and analyzation of loss } \\
\text { exposures }\end{array}$ & / & / & $\checkmark$ \\
\hline & a. Evaluation and analysis & l & l & $\checkmark$ \\
\hline & $\begin{array}{l}\text { b. Assessment on the permissibility and } \\
\text { acceptance of identified risks }\end{array}$ & $\mathrm{X}$ & / & $\checkmark$ \\
\hline \multirow[t]{3}{*}{ Control } & $\begin{array}{l}\text { 3. Selection of appropriate techniques } \\
\text { for treating the loss exposures sources } \\
\text { of potential losses are identified }\end{array}$ & / & / & $\checkmark$ \\
\hline & \multicolumn{4}{|l|}{ a. Risk Control } \\
\hline & - $\quad$ Risk Avoidance & I & $\mathrm{X}$ & $\checkmark$ \\
\hline
\end{tabular}

https://doi.org/10.24035/ijit.19.2021.200 


\begin{tabular}{|c|c|c|c|c|c|}
\hline & - $\quad$ Risk Prevention & 1 & I & $\checkmark$ & \\
\hline & - $\quad$ Risk Reduction & 1 & 1 & $\checkmark$ & \\
\hline & b. Risk Finance & & & & \\
\hline & - $\quad$ Risk Retention & 1 & 1 & $\checkmark$ & \\
\hline & - $\quad$ Takaful (Islamic Insurance) & $\mathrm{X}$ & I & $\checkmark$ & \\
\hline & - Insurance (Risk Transfer) & 1 & $\mathrm{X}$ & $\checkmark$ & 3 \\
\hline & - $\quad$ Noninsurance/Hedging & I & l & $\checkmark$ & \\
\hline Monitor & $\begin{array}{l}\text { 4. Implementation and monitoring of } \\
\text { risk management program }\end{array}$ & / & / & $\checkmark$ & \\
\hline Report & $\begin{array}{l}\text { 5. Reporting on risk management } \\
\text { program }\end{array}$ & I & / & $\checkmark$ & \\
\hline
\end{tabular}

The interviews validated that currently risks in the provision of wakaf-zakat housings are managed according to conventional risk management practice. In addition, specifically risks present in construction works in the provision of wakaf-zakat housings are managed by the developers and consultants appointed by respective MAINs. This is due to shortage of resources i.e. expertise and human resource. All 8 respondents agreed that the synthesis list presented in Table 3 is considered an appropriate method and may be applicable as Shariah compliance risk management in managing risks in the provision of wakaf-zakat housings. However, some of the respondents in the opinion that certain steps require enforcement by the authorities i.e. respective MAINs. For example, technique in protecting risks via takaful need to be emphasized. The protection of risks via takaful is acknowledged and encouraged by the authorities, but some developers and consultants are required to procure insurance from the companies' insurance panels, hence there would be possibilities of conventional insurance involvement in the provision of wakaf-zakat housings. In addition, for completed houses and contents therein, it is up to the wakaf-zakat recipients as householders or houseowners to manage risk.

Upon the validation of the experts, a proposed shariah compliance risk management process for wakaf-zakat housings is produced. Figure 1 shows the shariah compliance risk management in the provision of wakaf-zakat housings.

Figure 1: Development of Shariah Compliance Risk Management in the Provision of Wakaf-Zakat Housings

\begin{tabular}{|c|c|c|c|c|}
\hline \multicolumn{5}{|c|}{ 1. CONTEXT } \\
\hline Understand Objectives & Internal and External Fa & ctors & Class & ification of Risks \\
\hline \\
\hline \multicolumn{5}{|c|}{ 2. IDENTIFICATION } \\
\hline $\begin{array}{l}\text { Classify Risks into Grou } \\
\text { design, product, politic, }\end{array}$ & $\begin{array}{l}\text { ncluding financial, legal, } \\
\text {, Shariah compliance) }\end{array}$ & $\begin{array}{l}\text { Identi } \\
\text { Factor }\end{array}$ & Risk & $\begin{array}{l}\text { Identify Hiera } \\
\text { and Prioritization }\end{array}$ \\
\hline
\end{tabular}

3. ASSESSMENT

\begin{tabular}{|l|l|l|l|}
\hline $\begin{array}{l}\text { Analysis of Cause of } \\
\text { Risks }\end{array}$ & Analysis of Risks Effects & $\begin{array}{l}\text { Measure Risks } \\
\text { Potential Impact }\end{array}$ & $\begin{array}{l}\text { Estimate Maximization } \\
\text { of Risk Occurrence }\end{array}$ \\
\hline
\end{tabular}

\section{RESPOND}

Strategies of Management Reactions to Strategies of Risk Respond Including Risk Avoidance, Risk the Identified and Classified Risks $\quad$ Mitigation, Transferring/Sharing Risk, and Acceptance of Risk

\section{MONITORING \& CONTROL}

Mitigation Arrangement for Each Critical Danger is Connected and Managed Legitimately 
Results from the study suggest that the management of risk in the development of housings is significant, but appears lackadaisical attitudes by the authority i.e. respective MAINs in terms of the important to manage risks in the provision of wakaf-zakat housings. More importantly, from the findings of the study, it is found that risks in the provision of wakaf-zakat housings are being managed through conventional risks management. The outcome of the study i.e. a synthesis list comprising of processes and steps in shariah compliance risk management in the provision of wakaf-zakat housings is produced. The synthesis list become basis for the development of a comprehensive shariah compliance risk management in the provision of wakaf-zakat housings. Findings of the study are considered beneficial as they offer opportunity for the authorities and experts to practice shariah compliance risk management especially in the provision of wakafzakat housings. The study focuses to review literature on the practice of conventional and Shariah compliance risk management, therefore further study is recommended to focus on the categorization, distribution, and allocation of risks for both zakat and wakaf in housings development. In addition, detail study on the risk management mechanism including its financial and operational models for zakat-wakat housings development is also recommended.

\section{Acknowledgements}

1. The study is an extended research on the protection of wakaf-zakat properties for the needy and poor via takaful published in E-Proceeding 4th International Conference On Masjid, Zakat And Waqf Management 2017 (I-MAF 2017), pg. 157-171, ISSN: 9789671308738.

2. This research is funded by the Ministry of Higher Education (MoHE); TRGS Project Grant Ref. No. TRGS/1/2016/UIAM/01/3/5; Project ID: TRGS16-01-003-0003. Members of the grant are Asst. Prof. Dr. Puteri Nur Farah Naadia Mohd Fauzi (Principal Investigator), Prof. Sr. Dr. Khairuddin Abdul Rashid, Assoc. Prof. Dr. Azila Ahmad Sarkawi, Asst. Prof. Dr. Sharina Farihah Hasan, Asst. Prof. Dr. Srazali Aripin, \& Asst. Prof. Ir. Dr. Mohd Fairullazi Ayob. In addition, this research is part of research and study for post-doctoral scheme hosted by International Shariah Research Academy (ISRA) approved by IIUM; Ref. No. IIUM/202/C/1/1/7388.

\section{References}

Al-Quran.

Ashraf Md. Hashim \& Muhammad Ali Jinnah Ahmad. 2014. The Parameters of Permissible Risk in Takaful. ISRA Research Paper. Kuala Lumpur: ISRA

Asyraf Wajdi Dusuki. 2012. Principles and Application of Risk Management and Hedging Instruments in Islamic Finance. www.iefpedia.com/english/wpcontent/uploads/2012/07/Asyraf.pdf. Retrieved: March 24, 2017.

Khairuddin Abdul Rashid (1998). The Processes of Construction Procurement in Malaysia: Identification of Constraints and Development of Proposed Strategies in the Context of 'Vision 2020'. Unpublished PhD Thesis, The Nottingham Trent University, UK.

Mohd Fadzli Yusof, Wan Zamri Wan Ismail \& Abdul Khudus Mohd Naaim. 2015. Takaful: Operation and Business Competence. Kuala Lumpur: IBFIM

Mohd Nazri Chik. 2013. Shariah Governance Framework: Shariah Compliace Risk Management. Presentation in the 4th Asia Islamic Banking Conference, June 2013.

Nurul Shahnaz Ahmad Mahdzan \& Boey, A.O.L. 2015. Risk Management \& Insurance. Selangor, Malaysia: Oxford Fajar Sdn. Bhd.

Puteri Nur Farah Naadia Mohd Fauzi \& Khairuddin Abd. Rashid. 2017. Protection of Wakaf-Zakat Properties for the Needy and Poor via Takaful. Proceedings of the $4^{\text {th }}$ International Conference on Masjid, Zakat and Waqf Management 2017 (IMAF-2017). Kuala Lumpur

Ram Al Jaffri Saad, Norfaiezah Sawandi \& Rahayu Mohammad. 2016. Zakat Surplus Funds Management. International Journal of Economics and Financial Issues. Volume?: 171-176

https://doi.org/10.24035/ijit.19.2021.200 
Interview. 2019. Respondent 1 MAINs. The practice of risk management. 29 August.

Interview. 2018. Respondent 2 MAINs: Upon completion of construction works. MAINs 24 June.

Siti Mashitoh, M. 2006. Waqf in Malaysia: Legal and Administrative Perspective. Kuala Lumpur: University of Malaya Press

Syed Othman Alhabshi, Kamaruddin Sharif, Shaikh Hamzah Abdul Razak \& Ezamshah Ismail. 2012. Takaful: Realities and Challenges. Petaling Jaya, Selangor Darul Ehsan, Malaysia: Pearson Malaysia Sdn Bhd.

Tyser, C.R., Demetriades, D.G. \& Ismail Haqqi Effendi. 2001. Majallah El-Ahkam-i-Adliya. Kuala Lumpur: The Other Press. 